AL IBTIDA: JURNAL PENDIDIKAN GURU MI (2020) Vol 7 (1) : 69-84

DOI: http://dx.doi.org/ 10.24235/al.ibtida.snj.v7i1.5954

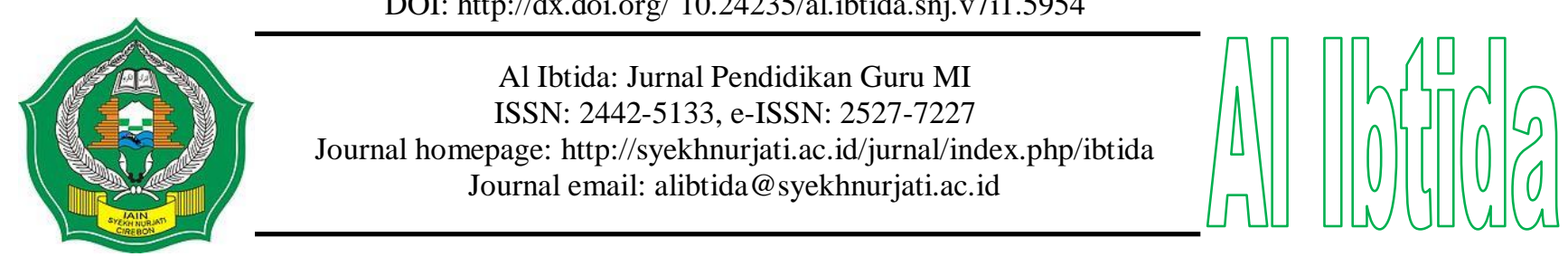

\title{
Internalization of Riau Malay Culture in Developing the Morals of Madrasah Ibtidaiyah Students
}

\author{
Syahraini Tambak* \\ *Departement of Islamic Religion Education, Faculty of Islamic Religion, \\ Universitas Islam Riau, Pekanbaru, Indonesia. \\ Email: syahraini_tambak@fis.uir.ac.id \\ Siti Humairoh** \\ **Departement of Islamic Religion Education, Faculty of Islamic Religion, \\ Universitas Islam Riau, Pekanbaru, Indonesia. \\ Email: sitihumairoh@student.uir.ac.id \\ Muhammad Ali Noer*** \\ ***Departement of Islamic Religion Education, Faculty of Islamic Religion, \\ Universitas Islam Riau, Pekanbaru, Indonesia. \\ Email: m.ali_noer@fis.uir.ac.id \\ Mawardi Ahmad***** \\ ****Departement of Islamic Religion Education, Faculty of Islamic Religion, \\ Universitas Islam Riau, Pekanbaru, Indonesia. \\ Email: mawardi_ahmad@ fis.uir.ac.id
}

Received: February $03^{\text {th }}, 2020$. Accepted: April $04^{\text {th }}$, 2020. Published: June $07^{\text {th }}, 2020$.

\begin{abstract}
This study aims to describe the internalization of Malay culture in developing the morals of madrasah ibtidaiyah students through the role of the teacher. This type of research is a case study, with interviews and observations used as data collection techniques. Researchers conducted interviews with teachers and principals of madrasah, as well as observing the learning process and madrasah activities for one year. Data were analyzed by reducing the results found, making presentations, and attracting new meanings based on the data found. The results of this study showed that the internalization of Riau Malay culture in developing the morals of students was done through giving advice; giving motivation; giving warning; providing understanding; giving example; communicating with parents; protecting and looking after students; giving training; providing assistance; approaching; controlling; inviting; using learning methods; imposing sanctions; and giving reward. This study concludes that the moral development of madrasah ibtidaiyah students can be done by internalizing Riau Malay culture in the learning process both at school and at home.
\end{abstract}

Keywords: Malay culture, morals, madrasah students, learning process. 


\begin{abstract}
Abstrak
Penelitian ini bertujuan untuk mendeskripsikan internalisasi budaya melayu dalam mengembangkan moral siswa madrasah ibtidaiyah melalui peran guru. Jenis penelitian ini adalah studi kasus, dengan wawancara dan observasi dijadikan sebagai teknik pengumpulan data. Peneliti melakukan wawancara kepada guru dan kepala madrasah, serta melakukan observasi proses pembelajaran dan kegiatan madrasah selama satu tahun. Data dianalisis dengan melakukan reduksi terhadap hasil yang ditemukan, melakukan penyajian, dan menarik makna baru berdasarkan data yang ditemukan. Hasil penelitian ini menunjukkan bahwa internalisasi budaya Melayu Riau dalam membentuk moral (akhlak) siswa yaitu dengan memberikan nasihat; memotivasi; memberikan teguran; memahamkan; teladan; berkomunikasi dengan orang tua; mengayomi dan menjaga peserta didik; memberikan latihan; memberikan bantuan; melakukan pendekatan; mengontrol; mengajak; menggunakan metode pembelajaran; memberikan sanksi; dan memberikan reward. Penelitian ini menyimpulkan bahwa pengeembangan moral siswa madrasah ibtidaiyah dapat dilakukan dengan menginternalisasikan budaya Melayu Riau dalam proses pembelajaran, baik di sekolah maupun di rumah.
\end{abstract}

Kata kunci: budaya melayu, akhlak, siswa madrasah, proses pembelajaran.

\title{
INTRODUCTION
}

Morals undoubtedly play an important role and are the key to human success in life. Without morals, human life would be limping. Morals are one of the main pillars of community life throughout history. As written in a history, a nation becomes strong if it is supported by a strong character, and but a nation will collapse when its character is damaged (Sugrue, 2019). This also applies to Muslims who have experienced a period of glory, and one of the factors that supported the glory of Islam at that time was a noble character (Pamungkas, 2014). Moral education should make the ethical perspective of the subject - the person being educated - more structured, more salient to his or her first personal perspective and therefore more 'navigable'. If the generic aim of nudge strategies is to structure the subject's choice context to improve the quality of her choices, then the complementary role of moral exemplars is to enhance this 'navigability' (Engelen, Thomas, Archer \& Ven, 2018).

Essler \& Paulus (2020) revealed that caregivers' moral reactions to young children's moral transgressions are informative environmental responses for children's developing understanding of morality. One central question concerns by which age parents hold their children responsible for moral transgressions. Moral reactions are very crucial over the first years of life and lend support to theories of intuitive parenting. Habibah (2015) argues that morality in Islam is a virtuous behavior that must be expressed in the social life of society. The importance of moral is always discussed and considered because it serves as a controller of behavior that develop various virtues and truths of life. According to Mustopa (2014) a 
person can be said to have morality if his behavior is based on the teachings of Islam originating from revelation.

Moral becomes the developer of behavior in acting so that humans will have wholesome behavior in life. Humans who have morals will do the good deeds that will deliver the perpetrators of world and hereafter success (Tambak \& Sukenti, 2020; Fauyan, 2019). Recent studies demonstrate that a moral self-effect, the continuity in moral values, is crucial to the ascriptions of identity in and over time. Since Locke, personal identity has been referred to as a 'forensic' concept, meaning that it plays a role in the attributions of moral responsibility. If moral values are crucial to identity over time, then perceived changes in a person's set of values may reduce responsibility for past deeds (Lavin \& Prinz, 2019).

This study explores the efforts of Riau Malay cultural teachers to shape the morals of students. The issue of morals is always important to be explored; it has been widely proven by the studies that examine the similar scientific fields. Han (2017) studied about the neural correlates of moral sensitivity and moral judgment associated with brain circuitries of selfhood with an experimental approach. In addition, the study compared the neural correlates of moral sensitivity with the neural correlates of moral judgment, which are the two functional components in the Neo-Kohl model of moral functioning. Bruya \& Ardelt (2018) conducted a study about wisdom that can be taught: a proof-of-concept study for fostering wisdom in the classroom with an experimental approach. In the study, looking at moral issues is a crucial concern for schools to colleges. Rahmah (2016) then conducted a study on moral education by bringing up education in the family. Ritongga (2018) examined moral education by bringing up a strategy of Islamic religious education teachers in the moral development.

Jamil (2018) expressed that Islam in Malay brings the concept of adat in a broad and deep meaning that encapsulates the whole way of life interpreted as culture. The integration between Malay customs and Islamic teachings forms the basis of Malay customs based on the Sunnah and the Qur'an. Tunggak \& Salamon (2011) restored the glory of the Malay civilization to continue the cultivation of a culture of morality. The research result of Zaitun (2018) stated that strengthening character of students could through moral values in gurindam. Tuah, Stapa \& Munawar (2012) in their research stated that Malay identity is implementation of Islamic education through morals.

But, a study on Riau Malay cultural teachers shaping students' morals, so far, has not been found. Though the formation of morals is very relevant to be done through Riau Malay culture by the teacher where the student is located. Because Riau Malay culture has taken root in the people of Riau and has very strong moral values. Civilization has been held down for 
generations by the community both in families, schools, and communities. Tambak \& Sukenti (2018) state that Malay culture is based on custom based on syara', and syara' is based on Kitabullah. This phrase emphasizes that Islam is inherent and integrated into Riau Malay culture. In another phrase, it says "syara' and custom carries out".

Of the many researchers who have conducted research on morals, many have led to several solutions such as education in the family, studying the subjects of moral conduct, and studying Islamic Religious Education. However, there are still many students who do not prioritize morals in their relationships, for instance, with the older people. When teachers explain in the class, students are more likely to talk with their friends than listen to the teacher's explanation. There are also some other bad behaviors such as talking to the teacher with a loud voice, pointing something with the left hand, not asking permission when going out of class, and not greeting the teachers when walking or passing in front of them. Then, students who are doing immoral behavior to their peers are likely to speak harshly or have a bad voice, fight, mock friends, and so on. It turns out that, in Madrasah Ibtidaiyah Negeri 3 Pekanbaru, there are still many moral problems like that. Therefore, the role of the Riau Malay cultural teacher is very important in shaping the morals of the students.

These problems are proof that morals must continue to be fostered. Therefore, in the efforts to foster and shape the morals of teachers, Riau Malay culture is needed. Strengthening Malay cultural teachings about morals is necessary. It is said by Effendy (2006) that according to the belief of Malays people, people who give instructions and teachings must first show a commendable attitude and behavior. Based on the background and study of literature, the problem can be formulated as follows: "What is the process of internalizing the Malay culture of Riau in developing the morals of learners in the Madrasah Ibtidaiyah Negeri 3 Pekanbaru City through the efforts of teachers?". From the formulation of the problem, this study aims to determine the efforts of teachers to internalize the Malay culture of Riau in developing the morals of learners in Madrasah Ibtidaiyah Negeri 3 Pekanbaru, Indonesia.

\section{METHODS}

This research is a qualitative design with a case study approach. Ahmadi (2014) stated that qualitative research is research steps that produce descriptive data both of speech, writing and behavior, which can be observed from the subject itself. Rahardjo (2017) argues that case studies are a series of scientific activities that are carried out intensively, in detail and in depth about a program, event and activity, both at the level of individuals, groups, institutions, or organizations to gain in-depth knowledge about an event, usually, actual events. 
This research was conducted in Madrasah Ibtidaiyah Negeri 3 Pekanbaru City, Riau Province, Indonesia for one year. Data were collected through interviews and observations. Interviews and observations are the appropriate data collection methods to understand a person's character (Satori \& Komariah, 2011). Interviews and observations were conducted with teachers, principals, and students by asking questions and listening to the answers directly. The researchers asked various questions in accordance with the problem and research objectives in depth, day after day, and for months, with the aim of finding the true role of the Malay cultural teacher in shaping the morals of the students. Interviewing informants by outlining the main points of discussion, the researchers asked questions freely. The questions were not asked sequentially and the choice of words was modified to make the interview situation more relaxed. This was done because the informants felt that the questions asked were the same and repeated. Interviews were conducted in several places in the school environment. Observations were made to explore the behavior of teachers and students in the internalization of Malay culture in creating moral human beings in madrasah.

Data processing techniques were carried out simultaneously with data analysis. The researchers conducted investigation and collected the data through interviews, field notes, and other activities to answer the research question and present the findings. Then, the implementation was carried out since the beginning of the researchers took to the field by collecting all the data that was done intensively, the researchers began to do the questions (Ahmadi, 2014). Data processing and analysis is done by data reduction, data presentation, and drawing conclusions (Prastowo, 2014).

Researchers sharpen, classify, direct, discard unnecessary activities, and organize data in such a way (through interviews and documentation). During this process, the researchers choose which data are coded, discarded, and what stories are developed, until a conclusion is reached. Researchers present the data in the form of narrative texts. By looking at the data presentation, an understanding of what is happening will arise. What actions should be taken based on the understanding of the data presentation could also be determined. In this study, researchers matched the data from all respondents interviewed by rereading the writings of the interview record and pre-formed patterns.

\section{RESULTS AND DISCUSSION}

The findings of this study show that there are various methods of teachers in internalizing Riau Malay culture in developing student morals in studying at Madrasah Ibtidaiyah Negeri 3 Kota Pekanbaru, Indoensia, namely: 


\section{Giving Advice}

The Riau Malay culture teacher method in developing students' morals through internalization of Malay culture is done by giving advice. The giving of this advice is done when the teacher acts as the executor of the habit of virtue behavior, applies the example, makes awareness, and provides training and teachings about the Malay cultural virtues of behaving. Then, advice is also given by the Riau Malay culture teacher when modeling students with morality towards the community and the environment. When the Riau Malay culture teacher gives training and teaches the character of students and the community, the teacher also gives advice. A teacher revealed that: "by doing good behavior, I advise students that in life they must behave honestly. I explained that interpreter's behavior had a positive effect on every human person. I provide Malay cultural values related to honest behaviour".

The results of this study are in accordance with the findings of a study by Afandi \& Pribadi (2019) that Malay culture is not merely an academic text, but must be implemented in life. And advice is one of the most important forms of support for someone, in this case the teacher who seeks all means to shape the morals of his students (Johari \& Zahid, 2016). When delivering a message that contains advice, the teachers must look at the recipient of the message, this means that the message conveyed must be in accordance with the degree of understanding that they know or understand.

\section{Giving Motivation}

Internalizing Riau Malay culture in shaping the morals of students is done by providing motivation to all students of Madrasah Ibtidaiyah. The teacher gives motivation to madrasah students so that students get used to practicing good morals to the family, the teacher, and the community. Internalization by providing motivation is done by the teacher in the exemplary process so that students have a noble character in the social life. Exemplify the personality of Malays in their attitude and good words to parents, teachers, neighbors and the general public. At the time of learning, the teacher gives motivation to madrasah students by telling stories of Malay figures who have successfully built the nation. The teacher also motivates students by emulating the struggles of past Malay figures such as Sultan Syarif Kasim II, Raja Ali Haji and others. A teacher who is very consistent in practicing Malay tradition said: "I always motivate students to familiarize their noble parents with applying Malay customs in the family. I make it a habit that I use Riau Malay culture to be applied by students in their school behaviour".

The findings of this study corroborate a study conducted by Saifudin (2018) that motivating students from an early age to behave well toward parents, friends, and the other 
people is done by loving the nation's cultural values. The nation's cultural traditions can encourage students to love their country, their people, and also respect their culture. Aryani's (2017) research findings reveal that it is important for teachers to encourage students to apply the desired doctrine. Providing motivation so that students will do good morals is noble because it involves changes in behavior. Getting used to good behavior can be done by paying attention to the cultural values that have been developed well in the society.

\section{Give a Warning for Habituation}

The teacher accustoms students to morality with religion and family by giving a warning and reprimands students who do not heed the values of Malay culture about virtuous behavior in parents, teachers, family, religion, and society. In madrasah life, students are required to exemplify the Malay tradition in behaving. Teachers in madrasahs together reprimand the students whose behavior violates the tradition and morality. This was done so that madrasah students were accustomed to good behavior by paying attention to the Malay traditions held firmly by the community. A reprimand is given by the teacher to warn students to have good character in their lives, such as speaking, respecting teachers, peers, and learning morals. It also makes them aware of not repeating wrong actions, then replacing those actions with kindness. A madrasah teacher suggests: “We always give warning to students if they find those who behave not in accordance with the teachings of Islam and Malay traditions. We reprimanded accompanied by giving a warning not to repeat the wrong deeds. This is done to familiarize madrasah students from an early age with good behavior.

The results of this study reinforce a study by Maros (2016) that Malay politeness is reflected in the reprimand that is done for any deviant behavior. Malay culture is reflected by maintaining the sensitivity (guarding the hearts) of the listeners so that good ways are needed in practicing the tradition. A good way of reprimanding is done so that the message conveyed can be received consciously in full sincerity. Wibowo, Ramli \& Lukman (2016) revealed that overcoming students who have made a mistake should be professional. A professional attitude is indicated by giving a good and correct reprimand (without offending/mocking) towards any deviant behavior carried out by students.

\section{Provide Understanding Behavior}

Familiarize students with morality towards themselves, family, society and religion by providing an understanding of good behavior through historical Malay stories. This provision of understanding is exemplified by conveying various moral behaviors that are good to be accustomed to in daily life. The teacher gives an understanding of good behavior to make students aware so that they have morals for themselves, family, community, religion and the 
environment. Thus, learners realize the intentions of good deeds done and the ultimate goal for self-improvement. A madrasah ibtidaiyah teacher said: "An action will be carried out well when getting a good understanding of the benefits of the act. I advise them by giving them an understanding of the meaning of the actions and benefits found later. I also give an understanding of these behaviors for invite them to see the Malay traditions that develop in the community".

Parmini (2015) revealed that a student can implement good behavior with a good understanding of these forms of morals. This understanding can be done by telling the meaning of good moral behavior to students. The findings of this study are in accordance with the results of a study by Rozin \& Fatmawati (2018) which says that giving understanding to learners can be done by telling various stories beforehand related to the behavior of successful people so that they can get inspired and benefit. The method is an appropriate way of understanding students' knowledge and behavior in learning. Understanding the behavior possessed by students enables them to consciously apply it well (Tambak \& Sukenti, 2019).

\section{Be a Role Model among Students}

In developing students' morals, madrasah ibtidaiyah teachers should become a role model for their students. The teacher accustoms students in practicing an appropriate greeting, respecting other teachers, loving students, and performing worship sincerely. The teacher exemplifies ways of morality to students how to be confident, do worship well, and love learning. The teacher also exemplifies the learners how to behave in the environment by paying attention to the Malay culture in the community. Students are also given a moral training on the environment such as how to greet others, how to say greetings when meeting, how to greet guests, and others. Malay tradition is applied consistently in madrasahs. A teacher revealed: "In the madrasah environment, we apply good attitudes towards the school community, fellow teachers and students. We take the Malay tradition by inviting mutual cooperation, through picket activities in class, learning to solve problems together, and helping orphans in orphanages together. Misdar (2017) stated that exemplary is a part of the teachers' professionalism and this cannot be separated from other professional elements. Modeling is actualized in the learning process because students are happy to imitate certain habits and behaviors of those around them.

\section{Communicate with Parents}

Accustoming students to morality towards religious morals is done by communicating with parents. The teacher makes awareness of the students' morality towards their families and communities through an intense communication with parents. The teacher exemplifies a 
good way of communicating with parents so that together they educate students with respect to their families at home. Communication is formed intensively with parents in order to build the morals of students together. The teacher directs children at home to apply Malay cultural values in acting, speaking, and behaving towards peers, parents, and neighbors. Madrasah ibtidaiyah teachers revealed that: "We carry out communication to build the morals of students in schools and the community. For us parents are partners who can't be separated in building the character of this child. Students have limited time at school, while at home they have more time so parents must also understand how to educate children. Yenrizal, Aprianti \& Hurin'in (2018) revealed that communication plays an important role for human survival, especially in the learning and teaching process. Through communication, confidence can arise and attitude changes can occur because of information from others. Therefore, to resolve students' moral problems, the best way is to have communication between teachers, students, and parents.

\section{Nurture and Build Students' Harmony}

Madrasah teachers develop students' morals by nurturing and building harmony among people. The teacher at Madrasah Ibtidaiyah realizes that the provision of a harmonious environment is significant in building the morals of students. The sense of comfort and good harmony makes the students obedient to the madrasah's rules. Nurturing and safeguarding students is done by paying attention to the values of Malay culture that are polite and friendly so that they are moral towards their community. Guidance is carried out not only during lessons but also when outside class hours. For example, when students speak harshly to their friends, the teacher immediately reprimands him with soft words and affection.

The results of this study reinforce a study by Thamrin (2014) on the revitalization of Malay local wisdom in maintaining the environmental harmony, revealing that Malays have a strong and deep philosophy in protecting things, especially children who need education and become successors to their parents. Strong philosophy is not just a philosophy of speech in advice, point to teaching, poetry and myth but also poured in real life.

\section{Provide Training Islamic Behavior}

The effort of madrasah teachers to internalize the Malay culture in developing the morals of students is done by providing training and modeling. Teachers often give short exercises in good morals to students. This is done when learning takes place, resting, and when interacting with the teacher. Provision of this short training is unlike training in a large format, but is carried out through teaching a virtuous behavior when students make mistakes. The teacher accustoms students to improve behavior by directly applying the procedures for 
good behavior. At this time, madrasah teachers often ask students to carry it out with regard to the Malay cultural traditions in the community.

The findings support a study conducted by Bakti \& Safitri (2017) who says that guidance or training is included in the strategy to solve moral problems. In practice, a success in guiding students will occur if the mentor has the thought to succeed, and a healthy individual development will occur in healthy interactions between individuals and the environment. Training Islamic behavior also is part of humanistic education. According to Kurniawan (2019), humanistic education was indicated by the creation of learning conditions through the application of the principles of effective learning. Students contributed actively in finding and processing teaching materials. School viewed students as unique and intelligent individuals.

\section{Provide Assistance to Students}

Madrasah ibtidaiyah teachers have internalized the Riau Malay culture by providing assistance to develop the morals of students. This condition is actualized at the time of habituation of the Islamic behavior in every day. The teachers also become role models to the internalization of the Malay culture for the students and provide assistance when learners have difficulties in implementing good behavior in the community. Assistance is provided by the teacher by cooperating with Malay figures to implement good behavior in the association of children. Quite often students feel ashamed in carrying out acts of virtue, so this is where the teacher shows the best ways to children. The school cooperates with the Riau Malay Customary Institution in terms of actualizing Malay culture in schools and the community.

The assistance provided by the Riau Malay cultural teacher is to explain to them the importance of helping one another, how to help from the small things, what are the benefits of helping each other, and so on. This assistance is given by the teachers at the time of habituation, example, and teaching students with respect to their environment. Then, assistance was also given by the teachers when students practiced the moral virtues towards the community and the environment. The results of this study, reinforce the opinion of Susan (2019), who said that helping each other is a part of management, and management is always oriented systematically (understanding why and how people work together) to achieve a predetermined and beneficial goal for humans.

\section{Take a Persuasive Approach}

In developing student morals, teachers take a persuasive approach to get students accustomed to the madrasah rules. Teachers are also aware of doing good to students in various opportunities at the madrasah, both when meeting, studying, and also taking a break. 
When the learning process takes place, madrasah teachers choose a persuasive approach so that students have a high willingness to apply virtuous behavior. The persuasive approach is taken by the teacher by applying the values of Malay culture in developing the morals of students in madrasahs and also in the family. A teacher revealed: "We always apply Malay culture in schools so that they can more easily adopt virtuous behavior. The application of Malay culture was chosen alongside Islamic lessons to make it easier for students to recognize and apply good morals in their actions. In addition, every day we apply communication with parents to control children's behavior at home".

The findings of this study reinforce the results of Taqwa's (2016) study which suggested two types of approaches aimed at building the morals of students, namely persuasive approaches that change students to be better; and a qualitative approach directing students to practice good morals so that they become happy and get welfare of life. Thus they can learn well and be happy in the stage of their lives from childhood to adulthood.

\section{Controlling Student Behavior}

The efforts of madrasah ibtidaiyah teachers in internalizing Riau Malay cultural values to develop the morals of students are done by controlling or monitoring their behavior while in the madrasah and at home. Controlling in madrasahs is done by supervising classes when learning takes place, making pickets controlling behavior, controlling students when they are taking a rest. While at home, it is done through controlling their behavior by cooperating with parents through parental control books, communicating by cell phone with the homeroom teacher every night, and involving the surrounding community from Malay figures appointed by the parents' union at each location. The findings of the research reinforce a study conducted by Fitriyaningsih \& Bakhri (2018), which says that one of the various ways used to discipline students is by control, because control is a way of teaching students to be able to adjust to habits and values accordingly.

\section{Inviting Students to Love the Environment.}

This elementary level madrasah teacher raises awareness about the morality of students by inviting them to protect the environment. Protecting the environment is an important moral that students must realize and have. Riau Malay culture teaches humans to protect the environment as a place to preserve life. Moreover, Riau, an area that forest fires often occur, requires students' awareness of the importance of protecting the environment. Madrasah teachers teach students to have a moral towards the environment by taking care of land and forests. The teacher always invites students to protect the environment by planting trees, cleaning the environment and the yard, and not littering. The message delivered will be well 
received if the teacher who acts as the messenger first pays attention to his behavior, conditions, and background (Yenrizal, Aprianti \& Hurin'in, 2018). It proves that the messenger is very concerned about the recipient of the message by paying attention to his condition (both physical and psychological).

\section{Using Learning Methods}

The teachers use various learning methods as a way to develop students' morals by involving the tradition of learning in Riau Malay culture. The teacher exemplifies the appropriate learning method to make students aware of morality towards religion, teachers, and their environment. In building the morals of the students, the teacher uses several methods including lecture, group work, storytelling, drilling, question and answer, and demonstration. A madrasah ibtidaiyah teacher revealed: "We use various methods in developing the morals of students by considering the Malay culture that develops in the community. We must improve good teaching methods day by day so students can apply good morals in their activities. This madrasah has a target so that all students have an Islamic character that is based on the teachings of Islam and Malay culture itself". According to Munazir, Yusuf, Mujiburrahman \& Nur (2017), strategy has a basis or a scheme in achieving its goals. Meanwhile, the learning method is one of the ways to understand learning quickly, precisely, and easily. In another sentence, it is said 'al-thariqat ahamm min al-maddah', which implies that "the method is far more important than the material"; it is a reality that the communicative way of delivery is far more effective and favored by students even though the material delivered is actually not too interesting (Tambak \& Sukenti, 2019).

\section{Giving of Sanctions.}

Madrasah teachers make students aware in morality to themselves, teachers, parents and the community by giving sanctions. The provision of sanctions is done to raise students' to behave well towards others. The sanction is different from the warning that has been done before. The provision of sanctions is related to the form of actions that must be done as a form of violation of deviant acts. While giving a warning is applied by the teacher only at the verbal level to correct actions that have not reached the form of punishment or fines. Punishment is only an emergency way carried out by the teacher so that students will be aware not to repeat the deviant acts. Sentencing is intended to make students have a good social attitude in the community. They have a good social character by raising awareness of punishment in accordance with the psychological aspects of the students.

Bafadhol (2017) in his research stated that the way to prevent and minimize the tendency of students to defy is to provide appropriate sanctions whenever they make a bad 
mistake. According to the Laws and Regulations, article 39 paragraph (2) in the government regulation No. 19 of 2017 states that sanctions can be in the form of reprimands or warnings, both oral and written, and penalties that suit to the rules of education, teacher code of ethics, and regulations legislation.

\section{Give Rewards to Students}

The teacher not only gives punishment to students but also gives rewards to students who have good morals in every activity both at school and at home. The awarding is done once every two weeks on Friday. All homeroom teachers select the best students who have good morals, then report to the headmaster of the madrasah, and announced the names of the selected students in front of the students. The selected students are given coaching money and other prizes. The awarding is intended to motivate all students to behave well to all people and the social environment. Malay cultural behavior loves good deeds and avoids negative attitudes in life.

According to Zamzami (2018), an increase in the ability to develop the personality potential of students can be triggered by giving rewards. In the world of learning, rewards are given as prizes to students who have achievements. It is hoped that students who get a prize will be more motivated and encouraged to improve their performance. The award provides motivation for other students to have better morals in the future.

\section{CONCLUSION}

The results of this study found that the internalization of Riau Malay culture in developing the morals of students in Madrasah Ibtidaiyah Negeri 3 Pekanbaru City was carried out in various forms namely; providing advice and direction; providing motivation to students; giving warnings to students; providing understanding of good behavior; becoming a role model; communicating with parents; protecting students; providing training on wholesome behavior; providing assistance in good behavior; taking a persuasive approach; controlling the actions of students; inviting students to love the environment; using various learning methods; imposing sanctions; and giving rewards. Research findings contribute to theories of moral development such as autonomous morality and heteronomous morality. Moral development can be done with moral knowing, moral feeling, and moral action. In addition, the findings of this study contribute to the internalization of Riau Malay culture to develop the morals of madrasah ibtidaiyah students in Indonesia. The findings of this study also contribute in developing the theory of Riau Malay cultural internalization as local wisdom in shaping the morals of students. The internalization of Riau Malay culture is able to 
develop the morals of students since the elementary school age is a crucial instrument in addition to the teachings of Islam.

\section{REFERENCES}

Afandi, S. A. \& Pribadi, U. (2019). The Capability of the Riau Malay Customary Institution (LAM) in Realizing the Riau 2020 Vision. Masyarakat, Kebudayaan dan Politik, 32(2), 196-208.

Ahmadi, R. (2014). Metodologi Penelitian Kualitatif. Yogyakarta: Ar-Ruzz Media.

Aryani, S.A. (2017). Healthy-minded religious phenomenon in shalawatan: a study on the three majelis shalawat in Java. Indonesian Journal of Islam and Muslim Societies, 7(1), 1-30. https://doi.org/10.18326/ijims.v7i1.1-30.

Bafadhol, I. (2017). Sanksi dan Penghargaan dalam Pendidikan Islam. Edukasi Islami: Jurnal Pendidikan Islam, 4(8), 15-32

Bakti, C. P. \& Safitri, N. E. (2017). Peran Bimbingan dan Konseling dalam Pengembangan Karakter Anak. Jurnal Konseling Gusjigang, 3(1), 67-72.

Bruya, B. \& Ardelt, M. (2018). Wisdom can be taught: A proof-of-concept study for fostering wisdom in the classroom. Learning and Instruction, 58(1), 106-114. https://doi.org/10.1016/j.learninstruc.2018.05.001.

Effendy, T. (2006). Tunjuk Ajar Melayu (Butir-Butir Budaya Melayu Riau). Yogyakarta: Balai Kajian dan Pengembangan Budaya melayu.

Engelen, B. Thomas, A. Archer, A. \& Ven, N. V. d. (2018). Exemplars and nudges: Combining two strategies for moral education. Journal of Moral Education, 47(3), 98112. https://doi.org/10.1080/03057240.2017.1396966.

Essler, S. \& Paulus, M. (2020). When do caregivers begin to view their child as a moral agent? Comparing moral and non-moral reactions to young children's moral transgressions. Journal of Moral Education, 49(1), 56-72. https://doi.org/10.1080/03057240.2020.1722622.

Fauyan, M. (2019). Developing Interactive Multimedia through Ispring on Indonesian Learningwith the Insight Islamic Values in Madrasah Ibtidaiyah. Al Ibtida: Jurnal Pendidikan Guru MI, 6(2), 177-190.

Fitriyaningsih, K. \& Bakhri, S. (2018). Kontrol Sosial dalam Pembinaan Karakter Religius Peserta Didik Muslim di Sekolah Menengah Kejuruan Negeri 1 Dukuhturi Kabupaten Tegal. Jurnal Sosiologi Reflektif, 12(1), 87-96.

Habibah, S. (2015). Akhlak dan Etika dalam Islam. Jurnal Pesona Dasar, 1(4), 456-471.

Han, H. (2017). Neural correlates of moral sensitivity and moral judgment associated with brain circuitries of selfhood: A meta-analysis. Journal of Moral Education, 46(2), 276289.

Jamil, T. I. (2018). Pendidikan Budaya Melayu Riau Buku Sumber Pegangan Guru. Pekanbaru: Lembaga Adat Melayu Riau.

Johari, A. \& Zahid, I. (2016). Manifestasi Kesantunan Melayu dalam Ujaran Memberi dan Meminta Nasihat. Gema Online: Journal of Language Studies, 16(2), 298-306.

Kamaluddin, K. (2017). Pesan Dakwah. Fitrah: Jurnal Kajian Ilmu-Ilmu Keislaman, 2(2), 3758. 
Kurniawan, A. (2019). Optimization of Humanistic Education in the Integrated Islamic Primary School. Al Ibtida: Jurnal Pendidikan Guru MI, 6(1), 37-48.

Lavin, J. G. \& Prinz, J. (2019). Parole and the moral self: Moral change mitigates responsibility. Journal of Moral Education, 48(1), 32-46.

Maros, M. (2016). Strategi Kesantunan Melayu dalam Membuat Teguran. Jurnal Elektronik Jabatan Bahasa \& Kebudayaan Melayu, 3 (1), 7-20.

Misdar, M. (2017). Keteladanan Guru dalam Pembelajaran (Suatu Tinjauan Teoritis). AtTa'lim: Media Informasi Pendidikan Islam, 15(1), 1-16.

Munazir, R. Yusuf, Z. Mujiburrahman, M. \& Nur, M. (2017). Menjaga Kelestarian Lingkungan Maritim Pesisir yang Berkelanjutan di Kabupaten Pidie dengan Pendekatan Adat Laot. Jurnal Humaniora: Jurnal Ilmu Sosial, Ekonomi dan Hukum, 1(2), 71-78.

Mustopa, M. (2014). Akhlak Mulia dalam Pandangan Masyarakat. Nadwa, 8(2), 261-281.

Pamungkas, M. I. (2014). Akhlak Muslim: Membangun Karakter Generasi Muda. Jurnal Pendidikan UNIGA, 8(1), 38-53.

Parmini, N. P. (2015). Eksistensi Cerita Rakyat Dalam Pendidikan Karakter Siswa Sekolah Dasardi Ubud. Jurnal Kajian Bali (Journal of Bali Studies), 5(2), 275-289.

Prastowo, A. (2014). Metode Penelitian Kualitatif. Yogyakarta: Ar-Ruzz Media.

Rahardjo, M. (2017). Studi Kasus dalam Penelitian Kualitatif: Konsep dan Prosedurnya. Bandung: Alifa.

Rahmah,S. T. (2016). Peran Keluarga Dalam Pendidikan Akhlak, Jurnal Ilmu dan Teknik Dakwah, 4(2), 174-192.

Ritongga, M. J.(2018). Setrategi Guru PAI Dalam Mengembangkan Akhlaq Peserta Didik di SMPN 06 Siak Hulu Kabupaten Kampar. Pekanbaru: Fakultas Agama Islam Universitas Islam Riau.

Rozin, M. S. \& Fatmawati, F. (2018). Manajemen Dakwah Program Kisah Menawan Sang Teladan di Radio Rodja 75, 6 AM Bogor. Jurnal Darussalam: Jurnal Pendidikan, Komunikasi dan Pemikiran Hukum Islam, 10(1), 132-149.

Saifudin, A. (2018). Keterampilan Dasar Utama Guru dalam Pengajaran. Intizam, Jurnal Manajemen Pendidikan Islam, 2(1), 39-47.

Satori, D. \& Komariah, A. (2011). Metodologi Penelitian Kualitatif. Bandung: Alvabeta.

Sugrue, E. P. (2019). Moral Injury Among Professionals in K-12 Education. American Educational Research Journal, 57(1),43-68.

Susan, E. (2019). Manajemen Sumber Daya Manusia. Adaara: Jurnal Manajemen Pendidikan Islam, 9(2), 952-962.

Tambak, S. \& Sukenti, D. (2018). Implementasi Budaya Melayu dalam Kurikulum Pendidikan Madrasah Ibtidaiyah di Riau. Miqot: Jurnal Ilmu-ilmu Keislaman, 41(2), 234-257.

Tambak, S. \& Sukenti, D. (2019). Strengthening Linguistic and Emotional Intelligence of Madrasah Teachers in Developing the Question and Answer Methods. Miqot: Jurnal Ilmu-Ilmu Keislaman, 43(1), 111-129. 
Tambak, S. \& Sukenti, D. (2020). Strengthening Islamic Behavior and Islamic Psychosocial in Developing Professional Madrasah Teachers. Cakrawala Pendidikan: Jurnal Ilmiah Pendidikan, 39(1), 65-78.

Taqwa, T. (2016). Pendekatan Manajemen Peserta Didik. Kelola: Journal of Islamic Education Management, 1(1), 48-55.

Thamrin, H. (2014). Revitalisasi Kearifan Lokal Melayu dalam Menjaga Harmonisasi Lingkungan Hidup. Toleransi, 6(1), 90-106.

Tuah, A. H. M. Stapa, Z. \& Munawar, A. (2012). Memperkasakan Jati Diri Melayu-Muslim Menerusi Pendidikan Islam dalam Pengajaran Akhlak (Strengthening Malay-Muslim Identity through Islamic Education and Akhlak Teaching). Jurnal Hadhari: An International Journal, 7(1), 23-35.

Tunggak, B. \& Salamon, H. (2011). Mengembalikan Kegemilangan Tamadun Melayu-Islam Menerusi Pemupukan Budaya Niaga Berteraskan Akhlak. Sari, 29(2), 123-147.

Wibowo, S. A., Ramli, A. H., \& Nukman, I. (2016). Pengaruh Kohesivitas Kelompok Dan Ewuh Pakewuh terhadap Pemberian Teguran Atasan kepada Bawahan. Psikoislamika: Jurnal Psikologi Dan Psikologi Islam, 13(1), 19-28.

Yenrizal, Y., Aprianti, R., \& Hurin'in, Z. (2018). Komunikasi Profetik dalam Mengajak Santri Non Mukim Menghafal Al-Qur'an (Studi Kasus di Pondok Pesantren Al-Ittifaqiah Indralaya Ogan Ilir Sumatera Selatan). Jurnal Studi Sosial dan Politik, 2(2), 109-121.

Zaitun, Z. (2018, December). Penguatan Karakter Bangsa Melalui Nilai-Nilai Akhlak Gurindam Dua Belas (G12). Prosiding Sepeda (Seminar Pendidikan Dasar) PGSD FKIP Unpas, 1(1), 328-344.

Zamzami, M. R. (2018). Penerapan Reward and Punishment dalam Teori Belajar Behaviorisme. Journal Ta'limuna, 4(1), 1-20. 